Anais da Academia Brasileira de Ciências (2013) 85(1): 73-86

(Annals of the Brazilian Academy of Sciences)

Printed version ISSN 0001-3765 / Online version ISSN 1678-2690

www.scielo.br/aabc

\title{
Neotectonics in Marajó Island, State of Pará (Brazil) revealed by vertical electric sounding integrated with remote sensing and geological data
}

\author{
LENA S.B. SOUZA ${ }^{1}$, DILCE F. ROSSETTI ${ }^{2}$, VAGNER R. ELIAS ${ }^{3}$ and RENATO L. PRADO ${ }^{3}$ \\ ${ }^{1}$ Instituto de Geociências, Universidade de São Paulo, Rua do Lago, 562, Cidade Universitária, 05508-900 São Paulo, SP, Brasil \\ ${ }^{2}$ Divisão de Sensoriamento Remoto, Instituto Nacional de Pesquisas Espaciais, \\ Avenida dos Astronautas, 1758, Jardim da Granja, 12245-970 São José dos Campos, SP, Brasil \\ ${ }^{3}$ Instituto de Astronomia, Geofísica e Ciências Atmosféricas, Universidade de São Paulo, \\ Rua do Matão, 306, Cidade Universitária, 05508-900 São Paulo, SP, Brasil
}

Manuscript received on October 7, 2010; accepted for publication on July 31, 2012

\begin{abstract}
Studies suggest that the Marajó Island has experienced neotectonic activity during its latest evolution. However, there are no data demonstrating the presence of tectonic structures in its shallow subsurface. This work integrates vertical electric sounding, morphostructural lineaments, and geological data aiming to show fault control on the Late Pleistocene-Holocene sedimentation of this area. Resistivity values were related to mud $(<90 \Omega \mathrm{m}$ ), clayey sand (90 and $200 \Omega \mathrm{m}$ ), sand $(200$ and $500 \Omega \mathrm{m})$, as well as Fe-bearing sand and laterite $(>500 \Omega \mathrm{m})$. The latest values were related to the unconformity with lateritic paleosol at the top of the Barreiras Formation. Despite the values $\leq 500 \Omega \mathrm{m}$ of both the Barreiras Formation and the Late Pleistocene-Holocene unit, the latter was distinguished along four electric sections due to the presence of this unconformity, combined with the integration of available ${ }^{14} \mathrm{C}$, and luminescence ages of Quaternary sediments. The electric sections recorded several places with lateral interruptions of resistivity values within short distances, which were related to faults. The Miocene strata were vertically displaced by normal faults, giving rise to new accommodation space where Late Pleistocene-Holocene sediments were deposited. Fault reactivation was crucial to renew sedimentation in eastern Marajó Island during its latest evolutionary stage.
\end{abstract}

Key words: vertical electric sounding, faults, Quaternary, Marajó Island, remote sensing.

\section{INTRODUCTION}

Several previous publications have shown that Marajó Island, a low-lying terrain of the Amazonas mouth positioned almost at the sea level, had a dynamic geologic evolution during the latest Quaternary (Mantelli and Rossetti 2009, Rossetti and Valeriano 2007, Rossetti et al. 2008a, b, Miranda et al. 2009). According to these authors, the

Correspondence to: Dilce de Fátima Rossetti

E-mail:rossetti@dsr.inpe.br island experienced a severe rearrangement of its drainage basins in the last $40 \mathrm{ka}$, producing intricate paleochannel networks recorded in a sedimentary succession at least $125 \mathrm{~m}$ thick. The preservation of this exceptionally thick sedimentary record in flat areas requires creation of accommodation space contemporaneous to sediment deposition. Several indirect evidences support that sediment accumulation in the Marajó Island during the latest Quaternary is a response of tectonic reactivations, 
which would have culminated with the island separation from the mainland around the early to middle Holocene (Rossetti and Valeriano 2007, Rossetti et al. 2007, Rossetti 2010).

The above-cited contributions helped to show the complex geological evolution of an area at the mouth of the largest drainage basin on Earth in the last thousand years. Taking into account that this region is located in the North Equatorial Brazilian passive margin, one point of main concern that deserves to be further investigated is whether tectonic deformation played a significant role to generate space for sediment accumulation in a relatively recent geological time.

Subsurface studies applying geophysical tools are crucial for demonstrating the presence of faults in theMarajó Island, particularly considering thescarcity of outcrops as a consequence of the low topography. In this regard, a large data basis consisting of vertical electric sounding (VES) was built for this area in the last four decades (A.C. Tancredi, unpublished data, C.A. Bezerra, unpublished data, C.N. Kobayashi, unpublished data, G.M.L. Cavalcanti, unpublished data, J.L. Porsani, unpublished data, A.C. González, unpublished data). Although the acquisition of these data aimed only applications to water resources, the good results achieved have provided a large volume of information on lithology variation, stratal geometry, and distribution of the sedimentary units in the shallow (i.e., up to $100 \mathrm{~m}$ depth) subsurface. The present work provides an analysis of the distribution of resistivity values in eastern Marajó Island, integrating these data with remote sensing and available geological information to demonstrate that morphostructural lineaments mapped in surface have a tectonic expression in subsurface. This work represents the first contribution to show the unquestionable occurrence of tectonic deformation of Miocene and latest Quaternary strata in the Marajó Island, and it might contribute for the better understanding of the latest structural evolution of the Equatorial Brazilian passive margin.
Geological SETting

The Marajó Island, positioned in the northeast of the State of Pará (Fig. 1A), is part of a fluvio-marine complex of 49,606 $\mathrm{km}^{2}$ bounded by the Amazonas River (west), Pará River (south), Tocantins-Marajó Bay (east), and Atlantic Ocean (north). This area is located in a region of tropical climate, with mean

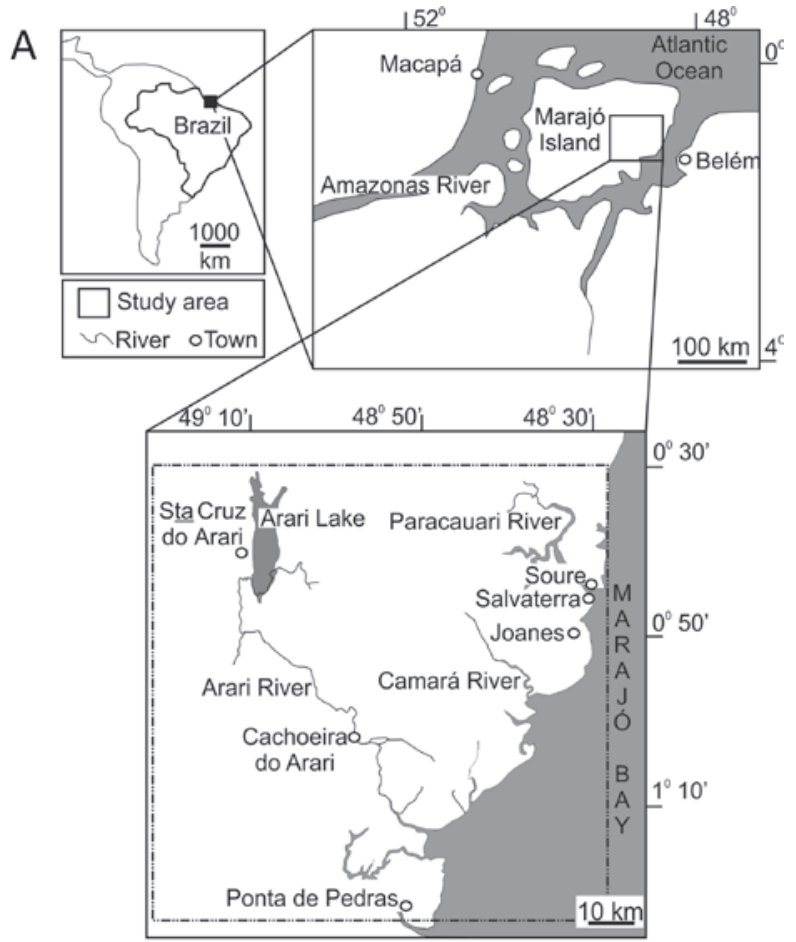

B

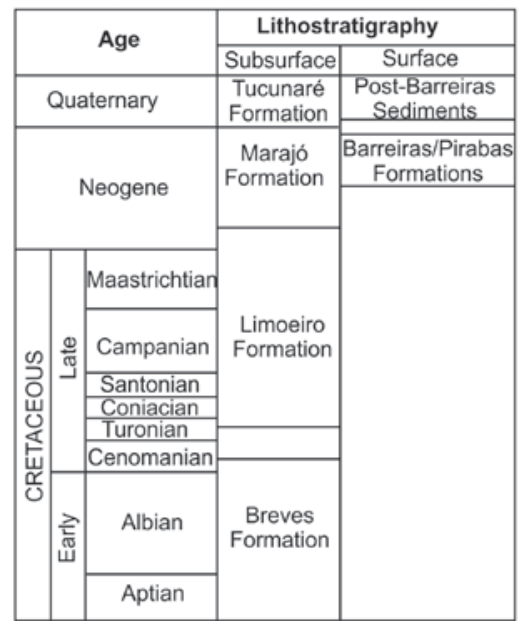

Fig. 1 - A) Location of the study area in eastern Marajó Island, State of Pará, Brazil. B) Summary of the stratigraphic framework of the study area (modified from Rossetti and Valeriano, 2007). 
annual temperature of $28^{\circ} \mathrm{C}$ and precipitation of 2,500 to 3,000 mm.year ${ }^{-1}$, being $90 \%$ concentrated between January and July.

The topography is dominantly low, with estimated topographic values between 2 and $42 \mathrm{~m}$. Digital elevation model (DEM) provided by the Shuttle Radar Topography Mission-SRTM indicates topographic values ranging from 4-6 $\mathrm{m}$ and 6-8 m in eastern and western Marajó, respectively, with an average topography of only $12 \mathrm{~m}$ for the entire island (Rossetti and Valeriano 2007). A great part of eastern Marajó, where the study area is located, is seasonally flooded at least 4 months per year. This area is characterized mostly by savanna, locally known as campo, with islands of dense tropical Ombrophyla forest. Campos consist mostly of grassland, cerrado (Miranda and Carneiro Filho 1994), and savanna woodland. Dense forest islands include terra firme and seasonally flooded várzea/gallery forests.

Geologically, Marajó Island is inserted in the western part of the Marajó Graben System and eastern part of the Pará Platform. The first is a NWSE trending graben formed during the African and South American rifting, initiated in the late Jurassic/ early Cretaceous (Szatmari et al. 1987). This structure shows geological and geomorphological features characteristical of Mesozoic extension and post-Miocene neotectonics (R.L. Bemerguy, unpublished data, Costa et al. 2002). There are three depocenters in this graben, related to the Mexiana (north), Limoeiro (central), and Cametá-Mocajuba (south) Sub-Basins, where an up to $11 \mathrm{~km}$-thick sedimentary pile was deposited. The Pará Platform is less known, corresponding to an extensive area that remained tectonically stable, but where small tectonic troughs with depth up to 3,500 $\mathrm{m}$ have been identified (Rezende and Ferradaes 1971).

In subsurface, the Marajó Graben System includes Cretaceous to Quaternary fluvial to transitional and shallow marine deposits (J.M. Villegas, unpublished data). Sandy deposits of the Breves/Jacarezinho Formations (Aptian-Cenomanian) and silty mudstones of the Anajás Formation (Cenomanian) are overlain by sandstones, mudstones and conglomerates of the Limoeiro Formation (Late Cretaceous). Cenozoic deposits consist of mixed siliciclastic-carbonates of the Marajó Formation (Paleocene-Eocene), as well as the Pará Group (Miocene to Holocene). The latter encompasses sandstones of the Tucunaré Formation and mudstones of the Pirarucu Formation. In the surface, eastern Marajó consists of Miocene (Pirabas/ Barreiras succession) and Pleistocene-Holocene deposits, the latter assigned generically to the lithostratigraphic term Post-Barreiras Sediments (Fig. 1B). The Pirabas Formation consists of carbonate deposits interbedded with shales and sandstones of transitional marine to inner shelf environments (Góes et al. 1990). The Barreiras Formation includes massive and stratified sandstone, laminated and massive mudstone, and heterolithic bedded deposits related to transitional estuarine environments (Arai et al. 1988, Rossetti et al. 1989, Rossetti 2008a, b, Rossetti 2001). The top of this unit is an unconformity marked by a lateritic paleosol that has been interpreted as resulting from the sea level drop started in the Tortonian, combined with a period of tectonic stability (Rossetti 2004, 2006). This discontinuity surface is overlain by the Post-Barreiras Sediments, consisting of massive fine- and medium-grained sandstones formed by debris flow and aeolian dune processes (Rossetti et al. 1989). Recent investigation integrating remote sensing and sedimentological data derived from cores has shown that great part of the Post-Barreiras Sediments in eastern Marajó Island records deposition in an estuarine system developed during the Late Pleistocene to mid-Holocene (Rossetti et al. 2008b).

A regional study has inserted the Marajó Island in a region encompassing a set of NW-SE normal faults, segmented by NE-SW and ENEWSW/E-W dextral strike-slip faults (cf. R.L. Bemerguy, unpublished data). Detailed mapping of the tectonic lineaments from the northeastern part of the island is still incomplete, recording only a few NW-SE and ENE-WSW/E-W lineaments. 
Morphostructural analysis led to the recognition of an important tectonic phase that produced NNW/ $\mathrm{SSE}, \mathrm{N} / \mathrm{S}$, and NNE/SSW lineaments predating all the other tectonic phases (Rossetti et al. 2007). According to these authors, subsequent events resulted in the displacement of NW-SE, and then NE-SW trending faults, with a consequent mild subsidence in eastern Marajó Island. E-W/ ENE-WSW/ESE-WNW lineaments might have developed in different phases, both predating and post-dating the other tectonic events.

The orientation of tectonic lineaments in Marajó Island conforms to the direction of main fault systems reactivated from Neogene to Holocene along the Brazilian Amazonia (e.g., Costa and Hasui 1997, Costa et al. 2002, Bemerguy et al. 2002). The significance of fault reactivations in this region is further supported by the distribution of several epicenters concentrated in eight seismogenic zones, where earthquakes of magnitudes up to 6.0 in the Richter's scale have been recorded (A.C. Miotto, unpublished data). One of these zones occurs at the mouth of the Amazonas River, where the Marajó Island is inserted, a place that has experienced earthquakes of magnitudes up to 4.8 in its northeastern side. Despite all these contributions, tectonic activity in Marajó Island remains to be better demonstrated with basis on mapping of tectonic structures in subsurface.

\section{MATERIALS AND METHODS}

This work is based on a total of 132 VES acquired in Marajó Island/PA. Amongst these, 111 VES represent data already available from previous studies (e.g., G.M.L. Cavalcanti, unpublished data, C.N. Kobayashi, unpublished data, J.L. Porsani, unpublished data); these were reprocessed and reinterpreted for the present study. The other 21 VES consist of inedited data acquired during this work (Fig. 2), completing the data collection in the adjacency of the towns of Cachoeira do Arari,
Salvaterra, Joanes and Ponta de Pedras (Fig. 1A). Data were acquired using a GEOTEST RD-300A resistivemeter, with a maximum power of $1,000 \mathrm{~W}$, reading interval of $0.1-750 \mathrm{mV}$, and maximum current value of $800 \mathrm{~mA}$. The electrode configuration used was a Schlumberger array with current electrode spacing $(A B / 2)$ varying from 1 to $320 \mathrm{~m}$.

Local artifacts (e.g., iron pipe, electric and/ or telephonic wiring) were carefully noted to have a control of their possible interference in the obtained values. A regular station distributed along the surface is desired for VES survey. The study area provides a regular VES data distribution due to reduced human activity and typical low topography. Electrode spacing was partially constrained only in the adjacency of the town of Salvaterra. After fieldwork, the newly acquired VES and the VES derived from previous publications were processed using the IPI2Win inversion program developed by GEOSCAN-M Ltd.

While the bulk of the VES data considered herein provided a broad insight of lithology distribution, the new data acquired during the present study aimed to record the subsurface expression of selected structures mapped with basis on remote sensing. These data included Landsat 5-TM (Ref. 224-060 and 225-061) and Landsat 7-ETM (Ref. 223-060 and 223-061, GLCF) images collected on August 2001, provided by INPEInstituto Brasileiro de Pesquisas Espaciais. A R (red) G (green) B (blue) band composition scheme was applied using the SPRING software. The composition 4(R), 5(G), 7(B) revealed the features of interest with the highest precision, providing the basis for mapping of morphostructural lineaments.

The electric sections and morphostructural lineaments were integrated with surface and subsurface geological data. Surface information included few exposures along coastal cliffs, as well as laterite and sand quarries. Subsurface data included sedimentological and ${ }^{14} \mathrm{C}$ dating derived from several cores up to $125 \mathrm{~m}$ of depth described in previous 


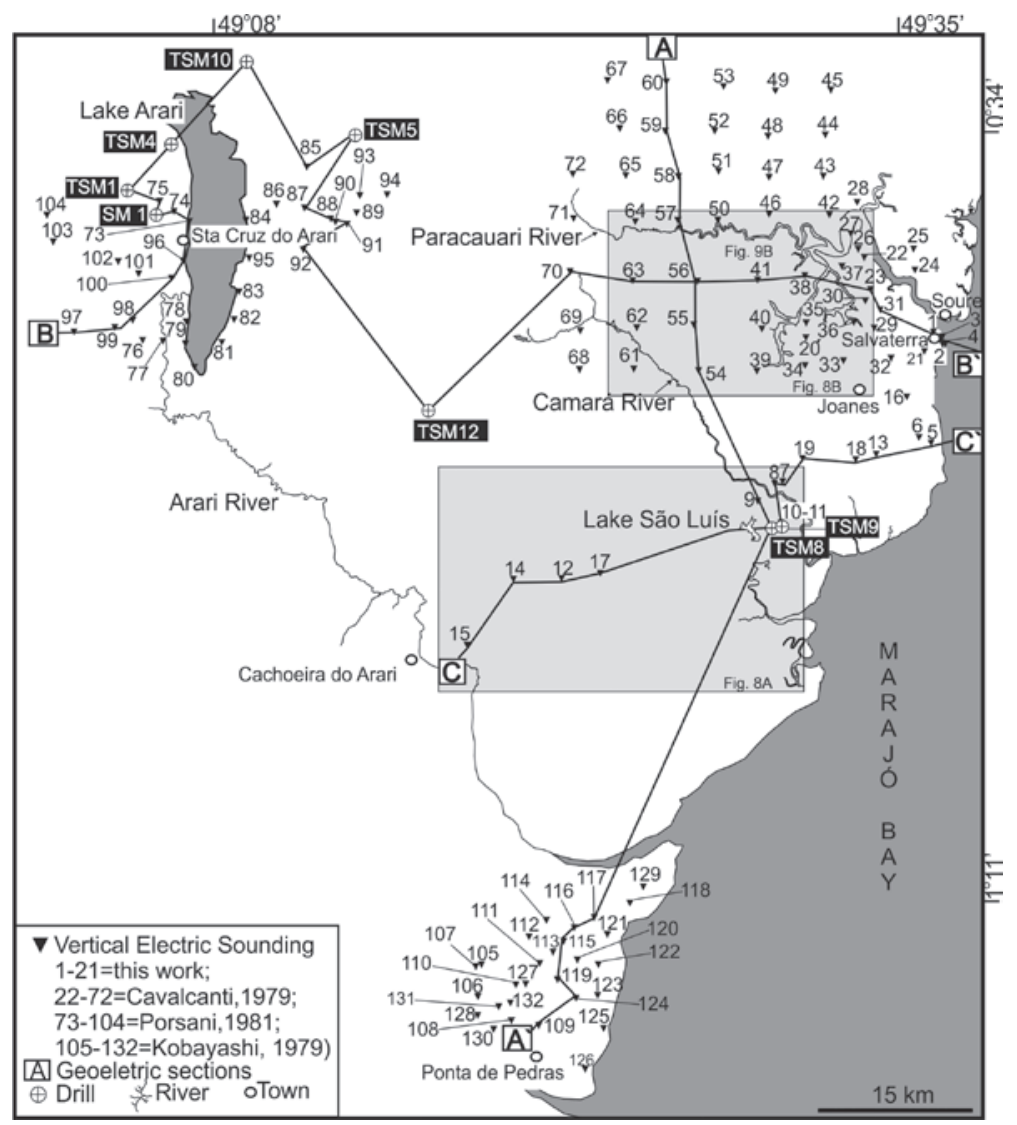

Fig. 2 - Map with location of individual vertical electric soundings (VES) and geoelectric sections shown in figure 5. Also shown are the locations of drills included in that figure.

publications (R.L., Bemerguy unpublished data, Rossetti et al. 2007, Rossetti et al. 2008b, Miranda et al. 2009, Castro et al. 2010, Rossetti 2010).

\section{SEDIMENTOLOGICAL AND STRATIGRAPHIC BACKGROUND}

The interpretation of the geophysical data was only possible because of their integration with geological information available from the Marajó Island. The sedimentary record exposed in the eastern part of this area includes the Barreiras Formation, comprising mostly highly weathered, massive mudstones and sandstones and, more rarely, conglomerates displaying variegated colors ranging from white to yellow, purple and red. These lithologies are locally endurated due to iron cementation. Best exposures of the Barreiras Formation are recorded along coastal cliffs in the adjacency of Salvaterra (Fig. 3A-D). As recorded in many other areas of the States of Pará and Maranhão (e.g., Rossetti 2004), the top of the Barreiras Formation in the study area is highlighted by an unconformity with pronounced erosional relief of several meters at the outcrop scale. This is accompanied by vertical columns of ferruginous concretions related to a paleosol of regional expression (Rossetti 2006). The concretionary horizon, usually not more than $3 \mathrm{~m}$ thick, is often overlain by an up to $0.5 \mathrm{~m}$-thick lag of laterite clasts and quartz pebbles. In some places, in situ lateritic paleosol is lacking, in which case it was replaced by the lag of laterite and quartz pebbles. Westward from coastal cliffs, the Barreiras Formation is exposed only along a few road cuts and small quarries, where the lateritic concretions and/or the lag of lateritic clasts and quartz pebbles are persistently present (Fig. 3E-G). 

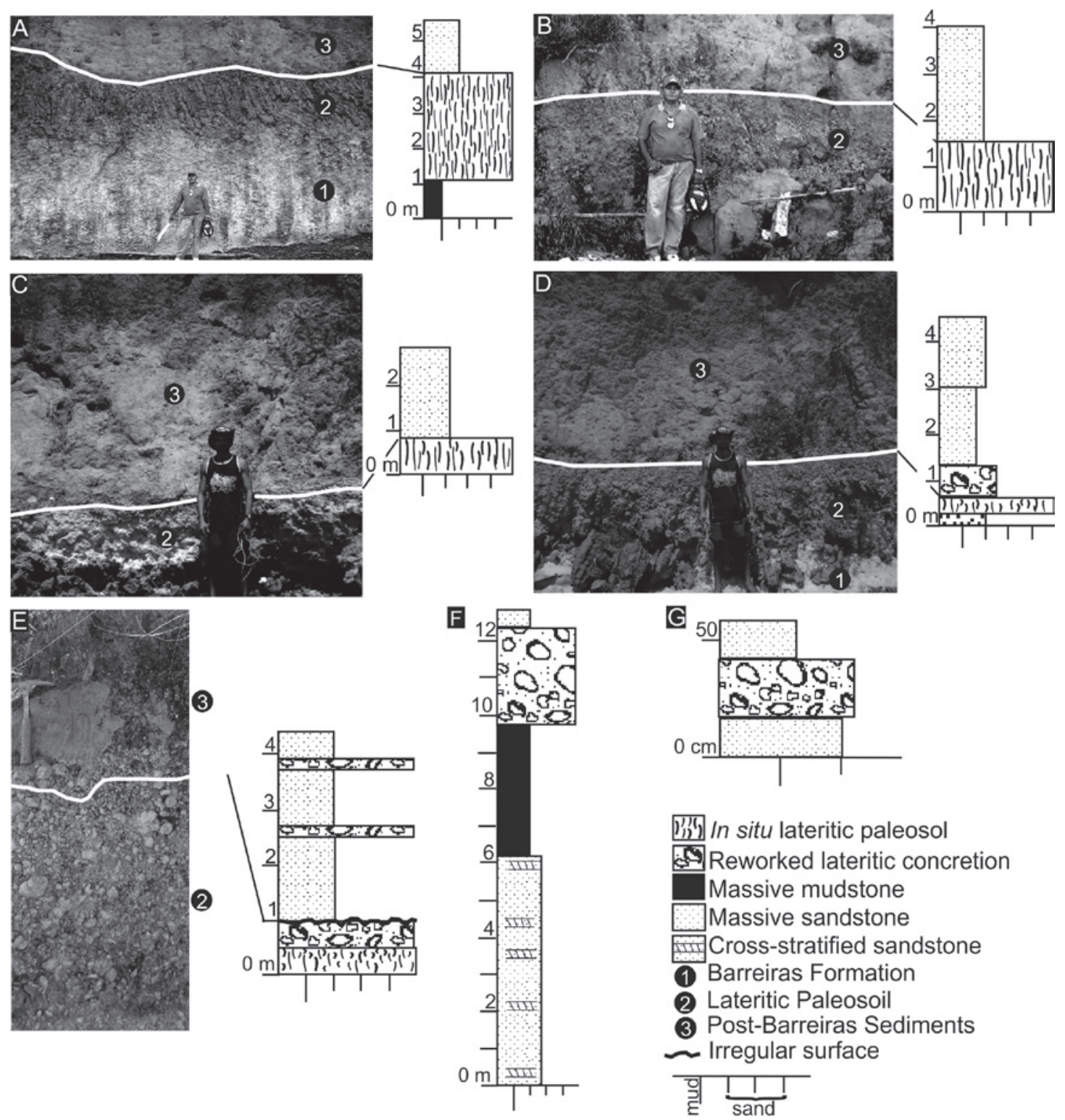

Fig. 3 - Exposures of the Barreiras Formation in a coastal cliff in Salvaterra (A-D, where VES 1 to 4 were acquired), in a road cut $(\mathbf{E}, \mathbf{G})$ and in a trench southwest of this town (F) (Hammer in $\mathrm{E}=35 \mathrm{~cm}$ long).

Where exposures were available, the Barreiras Formation is overlain by soft, bright yellow, massive, well to moderately sorted, quartzose, fine-grained sands with dispersed small coal fragments (Fig. $3 \mathrm{~A}-\mathrm{G})$. These deposits, which are up to $3 \mathrm{~m}$ thick, displayed only Late Pleistocene and Holocene quartz luminescence ages (Tatumi et al. 2008). Continuous cores from several drills up to $125 \mathrm{~m}$ thick, available westward of the area with exposures of the
Barreiras Formation and Post-Barreiras Sediments, have indicated only interbedded muds, sands and heterolithic deposits (Miranda et al. 2009, Castro et al. 2010, Rossetti 2010). These authors recorded numerous radiocarbon ages ranging between 55,082 $( \pm 12,354){ }^{14} \mathrm{C}$ yrs B.P. and to $3,184( \pm 37){ }^{14} \mathrm{C}$ yrs B.P. for these strata. Noteworthy is that the Barreiras Formation and the lateritic concretions in its top were not reached in any of the studied drills. 


\section{GEOELECTRIC DATA}

The resistivity values available for the study area vary from 0.4 to $13,662 \Omega \mathrm{m}$, with main concentration between 50 and $500 \Omega \mathrm{m}$. Taking into account the known geological characteristics summarized above, these electric data could be grouped into four categories related to the following lithologies: mud $(<90 \Omega \mathrm{m})$; clayey sand (90 and $200 \Omega \mathrm{m}$ ); sand (200 and $500 \Omega \mathrm{m}$ ); and Fe-bearing sand and laterite $(>500 \Omega \mathrm{m})$. The spatial distribution of geophysical data suggests that the highest values occur only in the northeast and southeast parts of the study area, mainly near the towns of Soure, Salvaterra, Joanes and Ponta de Pedras, where the Barreiras Formation is present. In these areas, the iron-bearing layers interpreted from the geophysical data reach up to $20 \mathrm{~m}$ thick.
The remaining of the study area, with very low to moderate resistivity values, occurs in association only with Quaternary deposits.

Inversion of VES data revealed four types of curves. Type 1 curve displays planar to smoothly convex shapes in the upper reaches that vary to concave at the bottom (Fig. 4A). This shape reflects highly resistive values near the surface (i.e., up to $10 \mathrm{~m}$ of depth), followed by an abrupt decrease, and then slight increase, in the highest depth. This curve type was the only one recorded in the areas with exposures of the Barreiras Formation, i.e, in the southeastern and eastern parts of the study area. In addition, it was also recorded in two electric sounding profiles (i.e., VES 15 and 14) nearby Cachoeira do Arari. Additionally, this curve was produced by inversion of three electric soundings (i.e., VES 8 to 10) collected nearby Lake São Luís.

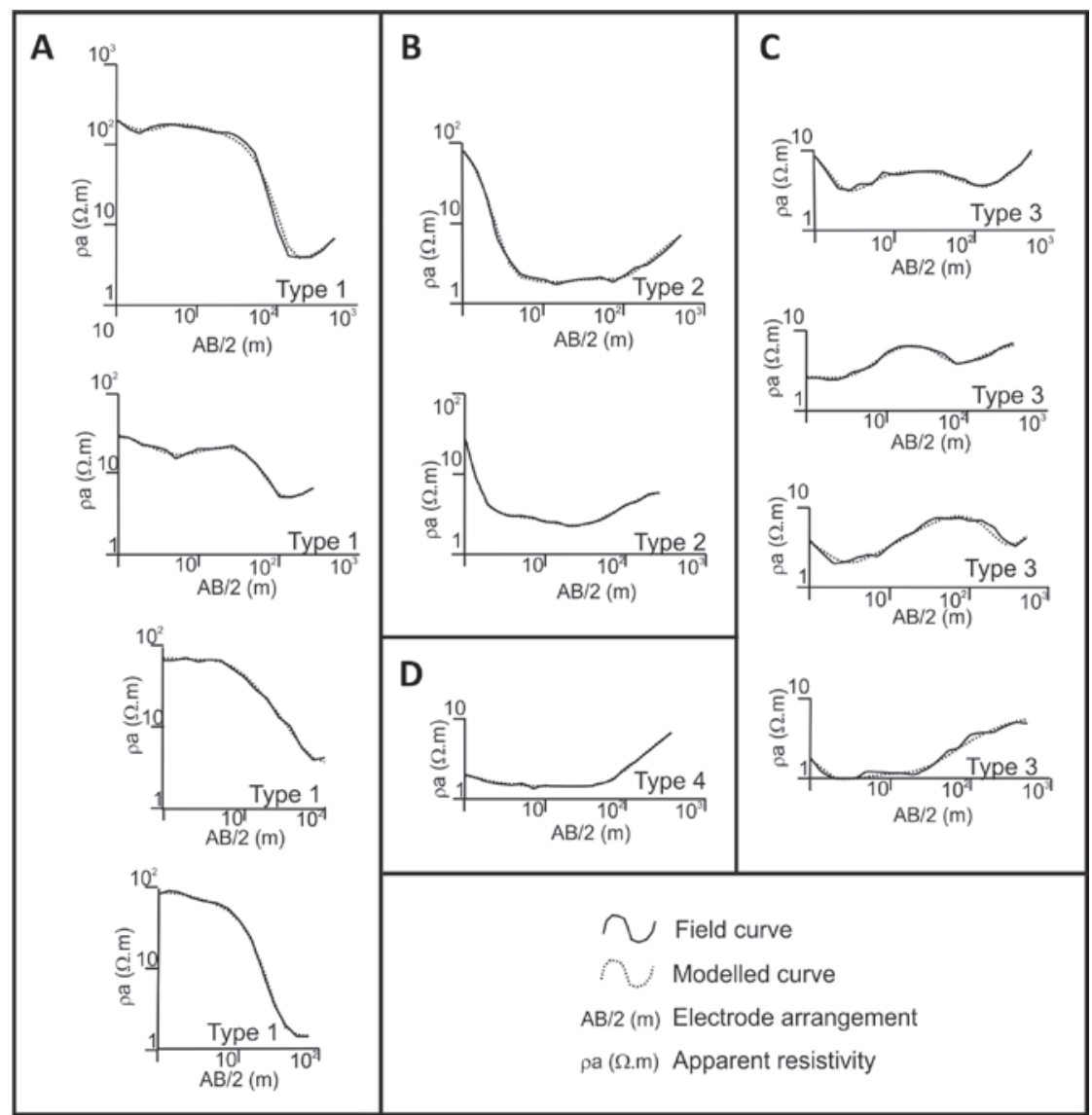

Fig. 4 - A-D) Types of resistivity curves derived from vertical electric soundings (VES) data. 
Type 2 curve is characterized by a pronounced but broad concave shape, a reflex of low conductive values at the shallow surface that suddenly increase with depth, where resistivity stabilizes and then increases rapidly at the highest depth (Fig. 4B). This curve type was most typically recorded in the Paracauari area. It was also present in several electric soundings in the adjacency of Lake Arari, as well as in VES12, VES14 and VES17, located nearby the town of Cachoeira do Arari.

Type 3 curve is defined by two smooth concave areas, separated by either a smooth or abrupt convex up area (Fig. 4C). This shape reflects dominantly low resistivity values, with two peaks of slightly higher conductivity with depth. Type 3 curve is the prevailing one in the Lake Arari area, though it was also indicated in all electric soundings collected in the Paracauari River, with exception of those distributed closer to the river course (i.e., VES 22, 23, 26, 27, 42, 46, 50, 57, $64,71)$. A variation of this curve, characterized by only one well defined concave peak at higher depth, was recorded in the VES 87 to 91 from the eastern margin of Lake Arari.

Type 4 curve is defined by a mostly planar shape with a steep edge to the right, reflecting low conductive values at the low and moderate depths, followed by an abrupt change to even less conductive values at the highest depth (Fig. 4D). Numerous electric soundings derived from the Lake Arari area recorded this curve type, with exceptions of a few ones located in its eastern margin, i.e., VES 87 to 91, where the modified type 3 curve was also documented. Additionally, type 4 curve was recorded in the same electric soundings of the Paracauari River where type 3 curve was present.

DESCRIPTION AND INTERPRETATION OF GEOLOGICAL SECTIONS

Three geologic sections (AA', BB' and CC') (Fig. 5) up to $90 \mathrm{~m}$ deep were elaborated for the study area to demonstrate the distribution of the deposits with depth, interpreted based on the integration of both electric and geological data.

Section A-A' (Fig. 5A) is representative of a north-south oriented, $105 \mathrm{~km}$-long transect that cuts through the Paracauari and Camará Rivers, and extends up to the town of Ponta de Pedras in the eastern part of the study area (Fig. 2). VES data indicate that the northern part of this section contains only resistivity values $<90 \Omega$ m that was related to the overall prevalence of mud. Analysis of Landsat images revealed that this area is dominated by meandering paleochannel deposits of the PosBarreiras Sediments. The southern part of section A-A' shows the highest resistivity values near the surface. This area is closer to the eastern margin of Marajó Island, where lateritic paleosols and Fecemented strata resulting from soil formation at the top of the Barreiras Formation are widespread. Therefore, deposits with lower resistivity values underlying this interval of high resistivity values were related to mud, and secondarily, lenses of clayed mud and sand included in the Barreiras Formation, although these values also might correspond to deposits older than this unit.

The central part of section A-A' intercepts an $18 \mathrm{~m}$-thick core consisting of deposits with ages up to $41,080( \pm 810){ }^{14} \mathrm{C}$ yr B.P. These are probably the fill of a Late Pleistocene paleochannel cut down into the Barreiras Formation, as suggested by their occurrence in an area with prevalence of high resistivity values related to this unit. Noteworthy is that this core was collected in the eastern margin of Lake São Luís. Analysis of Landsat images led to suggest that this lake is elongated and branched (Fig. 6A), representing most probably a residual channel that became intercepted through time, converting into the lake. This interpretation is consistent with several other lakes of comparable size and geometry located to the north and northeast, which can be laterally interconnected with Lake São Luís (see dotted 

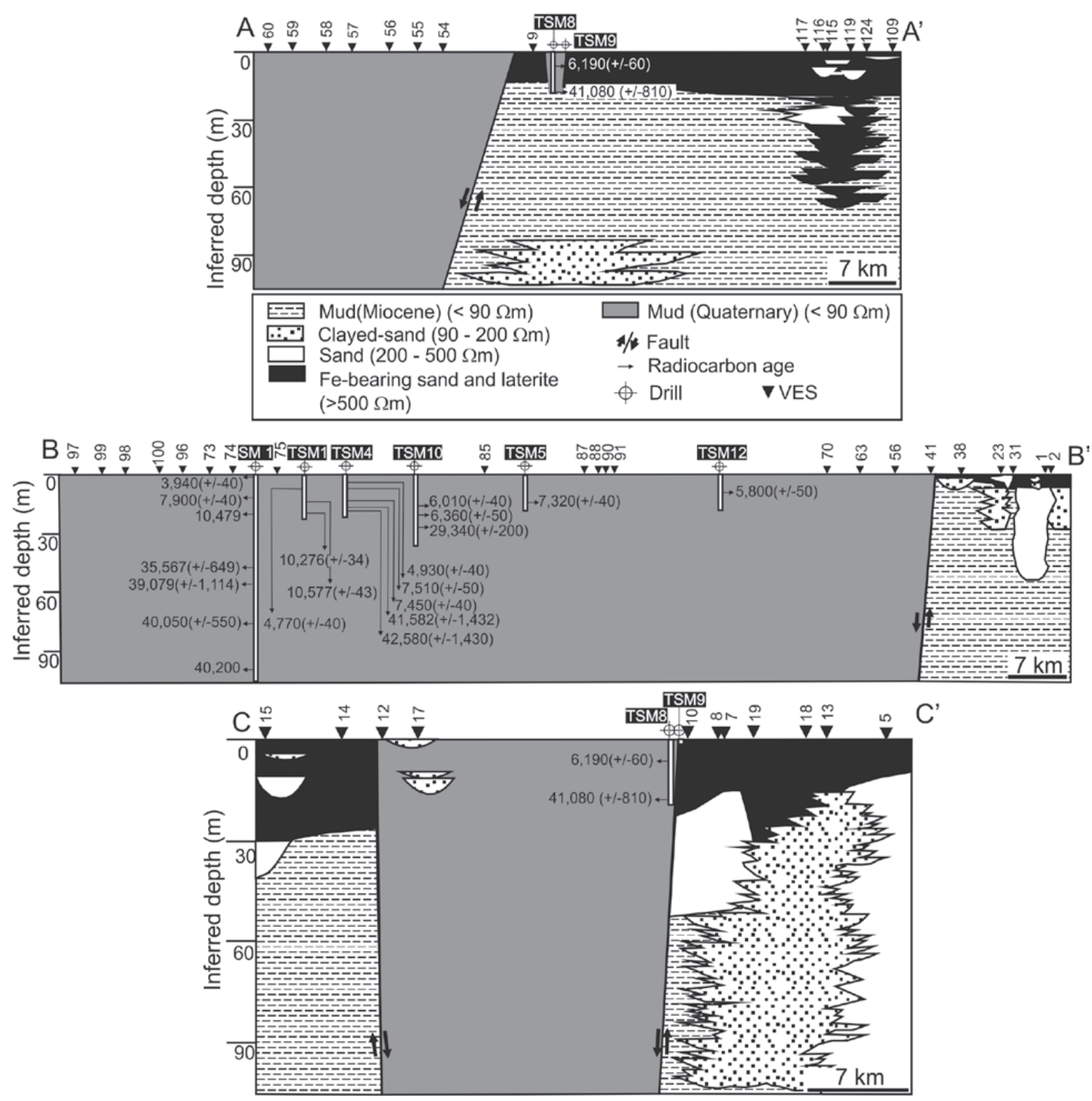

Fig. 5 - Geological sections interpreted from vertical electric soundings integrated with core data along transect A-A' (A), B-B' (B) and C-C' (C) (see figure 2 for location). Faults indicated in sections A-A', B-B' and C-C' are in agreement with the morphostructural lineaments marked by river courses shown in figure $6 \mathrm{~A}$ to $\mathrm{C}$, respectively.

white lines within the large rectangle in figure 6A). A previous study has suggested that the abandonment of this channel, as well as of many other channels in Marajó Island, might be due to fault reactivation (Rossetti etal.2008b). Analysis of Landsat images revealed several morphostructural lineaments in this area defined by modern straight river channels that suddenly change courses at angles close to $90^{\circ}$ (see white arrows within the inside rectangle in Fig. 6A), which are consistent with the suggested tectonic influence. Noteworthy is that Lake São Luís occurs in association with a NW-SE trending lineament, and it is in lateral continuity with an elongated lake segment that 
defines a NE-SW trending lineament (see yellow arrows within the rectangle in figure 6A). The present analysis of electric soundings indicates that this lineament matches perfectly well with the abrupt change from the Barreiras Formation into the Post-Barreiras Sediments between VES 9 and 54. These morphostructural features can be only accommodated in the presence of a fault.
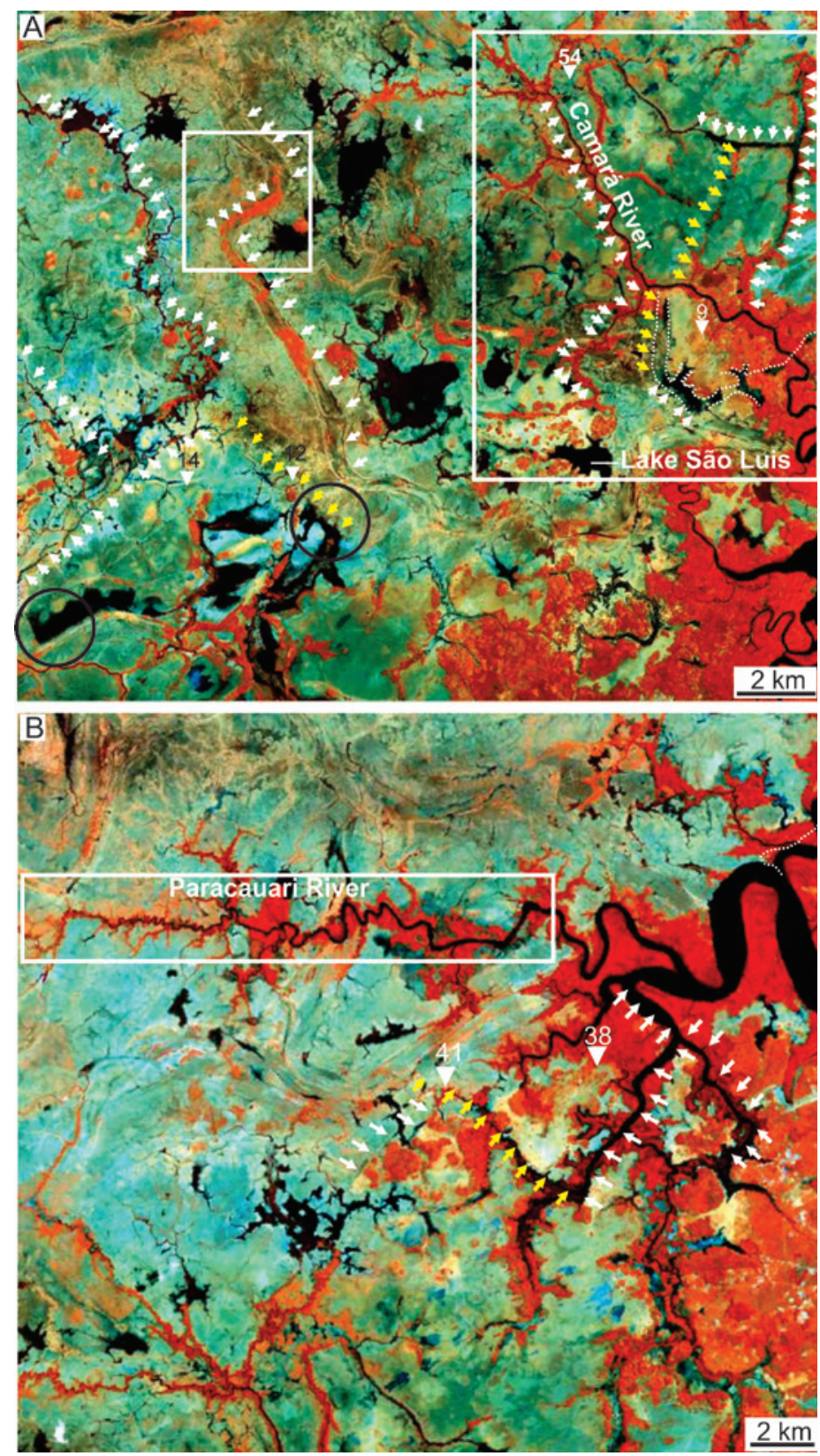

Fig. 6 - Landsat images (see Fig. 2 for location) illustrating morphostructural lineaments that coincide with the faults (yellow arrows) shown in sections A-A'(A), B-B' (B) and C-C' (A) illustrated in figures 5. Note the several other straight lineaments that intercept each other at right angles (white arrows). The larger and the small rectangles in A locate the area with the fault shown in section A-A', and the late Quaternary-Holocene paleochannel described in association with section C-C', respectively. Circles in this figure indicate sharply-bounded lake areas. The rectangle in B indicates where the Paracauari River displays several $90^{\circ}$ inflections in its course. See text for further explanations (red=forest; yellowish green or blue $=$ campo; black=water; numbers $=$ VES profiles $)$. 
Section B-B' (Fig. 5B) is located in the northern part of the study area, where it records a nearly E-W, $150 \mathrm{~km}$-long transect that intercepts the northern portion of Lake Arari, and follows to the east paralleling most of the Paracauari River, ending in the town of Salvaterra (Fig. 2). This section is almost entirely represented by resistivity values $<90 \Omega \mathrm{m}$. Integration of this information with twenty ${ }^{14} \mathrm{C}$ datings derived from six drills at 11 to $124 \mathrm{~m}$ depth indicate that these are Quaternary deposits formed in the time interval between 42,580 $( \pm 1,430)$ and 3,940 $( \pm 40){ }^{14} \mathrm{C}$ yrs B.P. (Rossetti 2010). In contrast, the easternmost edge of this section recorded resistivity values near the surface comparable to the ones related to the Fe-bearing beds from the top of the Barreiras Formation reported in the southern portion of section A-A'. Similarly to that area, the remaining strata below this very low conductivity beds are underlain by a large volume of deposits with resistivity values $<90 \Omega \mathrm{m}$. Taking into account the stratigraphic context, these deposits are related to the Barreiras Formation. In addition to mud, a few areas of clayed-sand (90-200 $\Omega \mathrm{m}$ ) and sand (200$500 \Omega \mathrm{m}$ ) are also present as lenses right below the interpreted Fe-bearing beds.

The Paracauari River is highly meandering to the east, but suddenly straight westward (see rectangle in figure 6B). Several right angle inflexions in its course are highly suggestive of a tectonically-controlled river (Rossetti et al. 2008b). Tributaries from the right margin of this river configure a perfectly rectangular drainage pattern formed by a series of NE-SW and NW-SE trending river segments connected at right angle (see arrows in Fig. 6B). The southern segment of this rectangle is an overall straight segment crossed by VES 41, which is the last eastward record of late Quaternary deposits of section B-B'. Westward from this profile, these deposits change abruptly into the Barreiras Formation within a distance of only $<5 \mathrm{~km}$ (i.e., between VES 38 and 41).
In addition to the detection of a morphostructural lineament composing the described rectangular drainage, this strongly supports the presence of a fault in this area.

Section C-C' (Fig. 5C) is the shortest one, comprising a nearly NE-SW trending, less than $60 \mathrm{~km}$-long transect that connects the electric soundings located close to the towns of Cachoeira do Arari and Joanes, which crosses section A-A' near Lake São Luís (Fig. 2). This section is more variable than the previously described ones, consisting of up to $30 \mathrm{~m}$ thick intervals characterized by high resistivity values at the surface in both of its edges. Deposits underlying the interval with high resistivity values in its northeast edge display various proportions of mud $(<90 \Omega \mathrm{m})$, clayedsand (90-200 $\Omega \mathrm{m})$ and sand (200-500 $\Omega \mathrm{m})$. To the southwest, these deposits are more homogenous, being attributed only to mud due to the prevalence of electric values $<90 \Omega \mathrm{m}$, with one small occurrence of sand displaying values between 200$500 \Omega \mathrm{m}$ in VES 15 . In contrast, the central part of section C-C' is mostly represented by mud deposits $(<90 \Omega \mathrm{m})$ up to the surface. Similarly to the other sections, the contacts between these deposits and the ones with the intervals of low conductivity on both sides of section C-C' are typically sharp.

${ }^{14} \mathrm{C}$ dating derived from core data indicates that the mud deposits from the central part of section C-C' was formed in the late Quaternary, with ages up to $42,080( \pm 810){ }^{14} \mathrm{C}$ yrs B.P. in the drill TSM8. Similarly to the other sections, these Quaternary deposits are in sharp lateral contact with the Barreiras Formation on both edges of this section, supporting that they were formed in a fault-bounded tectonically subsiding trough. The northeastern fault is the one that appears in section A-A', which occurs nearby Lake São Luís. The southwestern fault corresponds to a NW-SE trending morphostructural lineament that parallels other lineaments in this area, as the one defined by the Camará River (Fig. 6A). 
Some of these lineaments impose sharp margins in elongated, branched lakes (see circles in figure 6A). Similarly to Lake São Luís, these lakes have shapes suggesting that they were part of a drainage network in the past. Noteworthy also is the paleochannel to the east of VES 12, which displays a long straight segment paralleling this fault. This paleochannel changes twice its course northward, configuring segments connected at $90^{\circ}$ (see small inside rectangle in figure 6A). This suggests that its course was also under effect of fault displacement, although the fault itself could not be recorded in the electric soundings due to the overall muddy nature of the late Quaternary strata.

Considering the chronology based on ${ }^{14} \mathrm{C}$ dating, estimations of sedimentation rates for the entire succession varies, in general, from 1.4 to 1.8 $\mathrm{mm} / \mathrm{yr}$, locally reaching up to $4.5 \mathrm{~mm} / \mathrm{yr}$.

\section{DISCUSSION}

Lithological interpretation based only on electrical sounding might be troublesome, as this method is not able to distinguish thin beds. The resistivity values are closely related to the type, grain size, volume, and geometric distribution of the lithologies in subsurface. These altogether influence the electrical measurements from a given spacing and array of electrodes. Thus, VES data should be taken as an average value within a package that is rather not homogeneous. For instance, the resistivity of muddy deposits might increase when interbedded with sands. This is well illustrated in the study area by the overall high conductive nature of the of the late Quaternary mud deposits, as indicated by the prevalence of resistivity type 3 and 4 curves. Analysis of core data indicates that these correspond to mud deposits often interbedded with fine-grained sand beds. These strata could not have been distinguished from similar lithologies of the Barreiras Formation with basis only on VES data. The lateritic paleosol and the associated sandstones with iron cement derived from this interval at the top of the Barreiras Formation were crucial stratigraphic markers. Based on sharp lateral interruptions of resistivity values within short distances, it was possible to detect areas displaced by faults.

A remarkable point to highlight from this study is that the faults inferred by the VES data showed correspondence with main morphostrutural lineaments extracted from landsat images. Based on this data integration, this work reinforces previous studies proposing that the Marajó Island experienced tectonic deformation after deposition of the Barreiras Formation (e.g., Rossetti et al. 2007, 2008a, Rossetti 2010). Fault reactivation might have induced renewed sedimentation during the late Quaternary, and resulted in deposition of the Post-Barreiras Sediments after a long period of stability, when the area was undergone to subaerial exposure, and development of a lateritic paleosol. Only with creation of new accommodation space favored by fault displacement, a significant sedimentary pile could have been preserved in subsiding areas of this topographically flat, lowlying area of the Amazonas lowland (e.g., Rossetti and Valeriano 2007).

Fault displacement might have been in effect even during or shortly after sediment deposition. This is suggested mostly by the presence of long straight paleochannel segments aligned paralleling the faults, and by its abrupt deviations at right angle, as recorded in section C-C'. The proposed replacement of drainage networks into several laterally interconnecting elongated lakes, as recorded in the adjacency of Lake São Luís, constitutes further support that tectonic activity controlled the evolution of the physical environment in a relatively recent geological time. The mapped lineaments corresponding to the faults detected by the electric soundings are mostly NE-SW and NW-SE oriented, which are directions conforming to main tectonic trends of Marajó Island (R.L. Bemerguy, unpublished data, Mantelli and Rossetti 2009). 
The highest resistivity values related to the Barreiras Formation in the adjacency of Cachoeira do Arari, Ponta de Pedras, Soure, Joanes and Salvaterra. The prevalence of low resistivity values in the remaining of the study area defines the latter as the main locus for the late Quaternary and Holocene deposits. The high concentration of paleochannel morphologies recorded over this area (e.g., J.L. Porsani, unpublished data, Rossetti et al. 2008a, Mantelli and Rossetti 2009), including the Arari paleoestuarine system recorded by Rossetti et al. (2008b), sustains this proposal.

It is noteworthy that the sedimentation rate (in general of 1.4 to $1.8 \mathrm{~mm} / \mathrm{y}$ ) estimated for the sedimentary succession approaches those recorded from areas with high tectonic activity (e.g., Nilsen and McLaughlin, 1985). This high sedimentation rate is expected in areas with strike-slip deformation, being consistent with the faults recorded in this region. Subsidence caused by tectonic deformation was crucial to create space to accommodate the studied sediment in Marajó Island, compensating the drop of nearly $50 \mathrm{~m}$ of global sea level during the last glacial (Shackleton 1988).

\section{FINAL REMARK}

Lithological interpretation of electric sounding data aiming stratigraphic reconstructions requires integration with geological information derived from other data basis. In the study area, Miocene and Late Pleistocene-Holocene units have similar resistivity values. However, the distribution of these units could be established in the shallow surface based on: 1. a lateritic paleosol at the top of the Miocene deposits, which has anomalously high resistivity values; and 2. age information derived from core samples of the Late Pleistocene-Holocene unit. Based on this approach, fault displacements could be interpreted along the studied sections. The significant results obtained from application of VES in eastern Marajó Island lead to recommend the continuity of the approach integrating this method with remote sensing information as a tool to increase the record of faults in the shallow subsurface of Marajó Island. The demonstration of tectonic structures affecting sediment deposition during the Late Pleistocene-Holocene in this area has significant implications for future studies focusing on the reconstruction of the geological evolution of the equatorial Brazilian passive margin.

\section{ACKNOWLEDGMENTS}

We are grateful to FAPESP for providing the financial support to this work through the project \# 004/15518-6. Dr. J. L. Gouvêa is also kindly acknowledged for releasing the resistivemeter from the Geophysical Institute of the Universidade Federal do Pará.

\section{RESUMO}

Estudos sugerem que a ilha do Marajó experimentou atividade neotectônica durante sua evolução final. Entretanto, não existem dados demonstrando a presença de estruturas tectônicas em subsuperfície. Este trabalho integra sondagem elétrica vertical, lineamentos morfoestruturais e dados geológicos objetivando mostrar que falhas controlaram a sedimentação pleistocênica tardiaholocênica nesta área. Valores de resistividade foram relacionados com sedimentos argilosos $(<90 \Omega \mathrm{m})$, areia argilosa (90 e $200 \Omega \mathrm{m}$ ), areia (200 e $500 \Omega \mathrm{m})$, e areia contendo ferro e laterita ( $>500 \Omega \mathrm{m}$ ). Os últimos valores foram registrados na porção leste da área de estudo e relacionados coma discordância com paleossolo laterítico do topo da Formação Barreiras. Apesar de que valores $\leq 500 \Omega \mathrm{m}$ ocorrem tanto na Formação Barreiras, como na unidade pleistocênica tardia-holocênica, esta última pode ser diferenciada ao longo das seções elétricas pela presença dessa discordância intermediária, combinado com a integração de idades ${ }^{14} \mathrm{C}$ e de luminescência de grãos de quartzo de sedimentos quaternários. As seções elétricas registraram vários locais com interrupções de valores de resistividade dentro de curtas distâncias, 
que foram relacionados a falhas. Estratos miocênicos foram deslocados verticalmente por falhas, resultando em novo espaço de acomodação onde sedimentos pleistocênicos tardios-holocênicos foram depositados. A reativação de falhas foi crucial para renovar a sedimentação no leste da ilha do Marajó durante seus últimos estágios de evolução.

Palavras-chave: sondagem elétrica vertical, falhas, quaternário, Ilha do Marajó, sensoriamento remoto.

\section{REFERENCES}

Arai M, Uesugui N, Rossetti DF AND Góes AM. 1988. Considerações sobre a idade do Grupo Barreiras no nordeste do Estado do Pará. An Congr Bras Geol 35: 738-752.

BemerguY RL, COSTA JBS, HASUI Y, BORGES MS AND SOARES Jr AV. 2002. Structural geomorphology of the Brazilian Amazon region. In: KLEIN EL, VASQUE ML AND ROSA CLT (Eds), Contribuições à Geologia da Amazônia, Belém: Soc Bras Geol, Núcleo Norte, Belém, p. 245-258.

CAstro DF, Rossetti DF AND Pessenda LCR. 2010. Facies, $\delta^{13} \mathrm{C}, \quad \delta^{15} \mathrm{~N}$ and $\mathrm{C} / \mathrm{N}$ analyses in a late Quaternary compound estuarine fill, Northern Brazil, Mar Geol 274: 135-150.

COSTA JBS AND HASUI Y. 1997. Evolução geológica da Amazônia. In: COSTA ML AND ANGÉLICA RS (Eds), Contribuições à Geologia da Amazônia, Belém: Soc Bras Geol, Núcleo Norte, Belém, p. 15-19.

Costa JBS, Hasui Y, Bemerguy RL, SoARes Jr AV AND VILLEGAS JMC. 2002. Tectonics and paleogeography of the Marajó Basin, northern Brazil. An Acad Bras Cienc 74: 519-531.

Góes AM, Rossetti DF, NogueIRA ACR AND TOLEDo PM. 1990. Modelo deposicional preliminar da Formação Pirabas no nordeste do estado do Pará. Bol Mus Paraen Emílio Goeldi, Sér Ciên Terra 2: 3-15.

MANTELli LR AND RosSETTI DF. 2009. Significado tectônico de lineamentos de drenagem no sudoeste da ilha do Marajó. Rev Bras Geoc 39: 1-13.

MirANDA IS AND CARNEIRO FILHO A. 1994. Similaridade florística de algumas savanas Amazônicas. Bol Mus Paraen Emílio Goeldi, Sér Bot 10: 249-267.

Miranda MCC, Rossetti DF AND Pessenda LCR. 2009. Quaternary paleoenvironments and relative sea-level changes in Marajó Island (Northern Brazil): facies $\delta 13 \mathrm{C}, \delta 15 \mathrm{~N}$ and C/N. Paleogeogr Paleoclim Palaeoec 282: 19-31.

Nilsen TH AND MCLAughlin RJ. 1985. Comparison of tectonic framework and depositional patterns of the Hornelen strike-slip basin of Norwary and the Ridge and Little Sulphur Creek strike slip-basins of California. In: BIDDLE KT AND CHRISTIE-BLICK N (Eds), Strikeslip deformation, basin formation and sedimentation, SEPM Spec Publ 37, p.79-103.
REZENDE WN AND FERRADAES JO. 1971. Integração geológica regional da bacia sedimentar da Foz do Amazonas. Petrobras/Depart Explor, Belém, Rela Int, 27 p.

RossETTI DF. 2001. Late Cenozoic sedimentary evolution in northeastern Pará, Brazil, within the context of sea level changes. J South Am Earth Sci 14: 77-89.

RossetTI DF. 2004. Paleosurfaces from northeastern Amazonia as a key for reconstructing paleolandscapes and understanding weathering products. Sedim Geol 169: 151-174.

ROSSETTI DF. 2006. The role of tectonics on the preservation of estuarine valleys in areas with low accommodation rates: examples from Upper Cretaceous and Miocene Successions in Northern Brazil. In: DALRYMPLE RW, LECKIE DA AND TILLMAN RW (Eds), Incised Valley in Time and Space, SEPM Spec Publ 85, p. 199-218.

RossETTI DF. 2010. Tectonic control on the stratigraphy framework of Late pleistocene and holocene deposits in Marajó Island, State of Pará, eastern Amazonia. An Acad Bras Cienc 82: 439-450.

Rossetti DF, GÓES AM, VAleriano MM AND Miranda MCC. 2008a. Quaternary tectonics in a passive margin: Marajó Island, northern Brazil. Journal of Quat Sci 23: 121-135.

Rossetti DF, GÓES AM, VALERIANO MM AND THALlÊS M 2008b. Paleodrainage in Marajó Island (northern Brazil) and its relation to Holocene relative sea-level dynamics. The Holoc 18: 923-934.

Rossetti DF, TRucKenbrodt W AND Góes AM. 1989. Estudo paleoambiental e estratigráfico dos Sedimentos Barreiras e Pós-Barreiras na região Bragantina, nordeste do Pará. Bol. Museu Paraense Emílio Goeldi, Sér Ciênc Terra 1:25-28.

RossetTI DF AND VALERIANO MM. 2007. Evolution of the lowest amazon basin modeled from the integration of geological and SRTM topographic data. Catena 70: 253-265.

Rossetti DF, VALERIANO MM AND THALlÊS M. 2007. An abandoned estuary within Marajó Island: implications for late quaternary paleogeography of northern Brazil. Estuar and Coasts 30: 813-826.

SHACKLETON NJ. 1988. Oxygen isotopes, ice volume, and sea level. Quat Sci Rev 6: 183-190.

SZATMARI P, FRAÇOLIN JBL, ZANOTTO O AND WOLFF S 1987. Evolução tectônica da margem equatorial brasileira. Rev Bras Geol 17: 180-188.

TATUMI SH, Silva LP, PIRES EL, RosSETTI DF AND GÓES AM 2008. Datação de Sedimentos Pós-Barreiras no norte do Brasil: implicações paleogeográficas. Rev Bras Geoc 38: 514-524. 